УДК 631.331:001.8 DOI 10.31210/visnyk2018.03.25

(C) 2018

Прасолов С. Я., кандидат технічних наук,

Бєловол С. А., кандидат технічних наук,

Черненко Б. С., Уэсищенко А. В., магістранти

Полтавська державна аграрна академія

\title{
ДОСЛІДЖЕННЯ ТА ОБГРУНТУВАННЯ РАЦІОНАЛЬНИХ ПАРМЕТРІВ ПЛІВКОУКЛАДАЧА
}

\section{Рецензент - доктор сільськогосподарських наук, професор П. В. Писаренко}

Наведено результати дослідження згідно методики нормативних документів. Визначено технологічні параметри плівкоукладача. Для зменшення трудомісткості і тривалості досліджень було використано матричне планування. Встановлено залежності параметрів оптимізації від впливових факторів: діаметра та кута нахилу трунтового покриття диска з кваліфікованою швидкістю; діаметру та глибини занурення трунтово-покривного диска та швидкості руху по висоті. Визначено вплив покриття поверхні трунту на динаміку випаровування вологи в залежності від часу спостережень. Встановлено вплив ширини плівки на термічний режим трунту. Результати досліджень опробовані в ПП Агрофірма «Анастасія» та ТОВ АФ «ім. Довженка» ВП АФ «Орданівка». Використання плівкоукладача має сезонний характер і окупиться за один рік.

Ключові слова: плівкоукладач, агротехнічні заходи, мульчування, міжряддя, обробіток грунmy, диск.

Постановка проблеми. Агропромислове виробництво залишається чи не єдиною галуззю економіки України, що зберігає зростання. Але його потенціал не використовується повною мірою, тому уряд та самі аграрії шукають нові шляхи розвитку i підвищення продуктивності та якості продукції сільського господарства. Так, Законом України «Про пріоритетні напрямки інноваційної діяльності в Україні» від 8 вересня 2011 року технологічне оновлення та розвиток агропромислового комплексу визнано стратегічним напрямом інноваційної діяльності на період з 2011 по 2021 роки, як і Законом України «Про виробництво та обіг органічної сільськогосподарської продукції та сировини» від 03.09.2013, що в ст. 18 визначає використання методів, що оптимізують біологічну активність грунтів, забезпечують збалансоване постачання поживних речовин рослинам, зберігаючи земельні та інші природні ресурси. Одним із шляхів такого використання є мульчування грунту неорганічними матеріалами, зокрема поліетиленовою плівкою та агроволокном. Попри доведену ефективність таких методів технічна база засобів для механізо- ваного укладання плівки залишається обмеженою, містить переважно саморобні агрегати для малопотужних технічних засобів та немає достатньої теоретичної та методичної бази для розробки серійних високоефективних машин.

Аналіз останніх досліджень і публікацій, у яких започатковано розв'язання проблеми. Вперше на початку 70-х років минулого століття в США використовувалась сівалка 3 пристосуванням рівномірного розкладання плівки для сівби цукрової кукурудзи, що дало приріст урожаю до 50 \%. Широкомасштабне застосування технології вирощування кукурудзи у Франції почалося 3 моменту створення поліетиленової плівки, яка розкладалася під дією променів сонця $[2,3,5]$. Пізніше у Франції, Німеччині, Італії, Чехії були проведені дослідження агротехнічних i економічних показників використання технологій обробітку кукурудзи під плівкою. У Франції на базі чотирирядної кукурудзяної сівалки була створена сівалка «Cadama» $[6,8]$. Відомими $\epsilon$ іноземні дослідження роботи плівкоукладачів для вирощування рису та овочів [7, 9, 10]. Там розглядались деякі конструктивно-технологічні параметри плівкоукладачів та показники їх техніко-економічної ефективності при застосуванні на відкритих грунтах. Проте досвід іноземних дослідників недостатній для ефективного впровадження таких технічних засобів в овочівництві в Україні. Серед наукових робіт вітчизняних вчених тема дослідження та обгрунтування раціональних параметрів плівкоукладачів досить обмежена. Наразі серед останніх публікацій у відкритих джерелах відомі результати дослідження кіровоградських вчених I. Осипової та I. Сисоліної, що стосуються розробки та дослідження плівкоукладача до кукурудзяної сівалки. Окремо приділена увага дослідженню теплового режиму грунту залежно від ширини плівки [1]. Широкі дослідження проводяться в УкрНДІПВТ ім. Леоніда Погорілого, які спрямовані на оптимізацію процесу виробництва зернових та технічних культур на значних посівних площах із викорис- 
танням широкозахватної техніки. Питання ж забезпечення технічними засобами мульчування для овочівництва та/або ягідівництва в Україні залишається малодослідженим. Однак розвиток саме цих галузей має велике значення для продовольчої безпеки України та підвищення експортного потенціалу галузі.

Мета досліджень: дослідження направлені на вдосконалення конструкції та обгрунтування раціональних параметрів плівкоукладача для міжрядного мульчування з метою підвищення якості розгортання і закріплення плівки та продуктивності процесу.

Завдання досліджень: встановити вплив діаметра та кута нахилу грунтово-покривного диска на робочу швидкість машини; визначити раціональні значення діаметра та глибини занурення грунтовопокривного диска та швидкості руху по висоті.

Результати досліджень. Для вирішення поставленої мети спершу було запропоновано технічне рішення, яке належить до покращення тепличного господарства [4].
При розробці плівкоукладача враховували наступні вимоги до конструкції. Рівномірна подача та укладання плівки з певним натягом досягається тим, що в плівкоукладача, який має раму, вал для кріплення рулону плівки, опорні колеса додатково встановлюються на основні стійки несучої рухомої рами і закріплюються універсальними фіксаторами стійки переднього розгортача, яким створюються смуги-заглибини, по ширині прикочуючих коліс та заднього підгортача грунту на плівку. По ширині рами встановлюються: вал 3 обмежувачами переміщення рулону та ніж для відрізання плівки. Але плівкоукладач має ряд недоліків: недостатнє розпушування грунту, нерівна поверхня грунту, відсутній датчик контролю витрати плівки, універсальний ніж, що обертається навколо вісі 3 фіксатором положення для відрізання плівки.

Перераховані вище недоліки враховані при розробці покращеного плівкоукладача, представленого на рисунку 1.
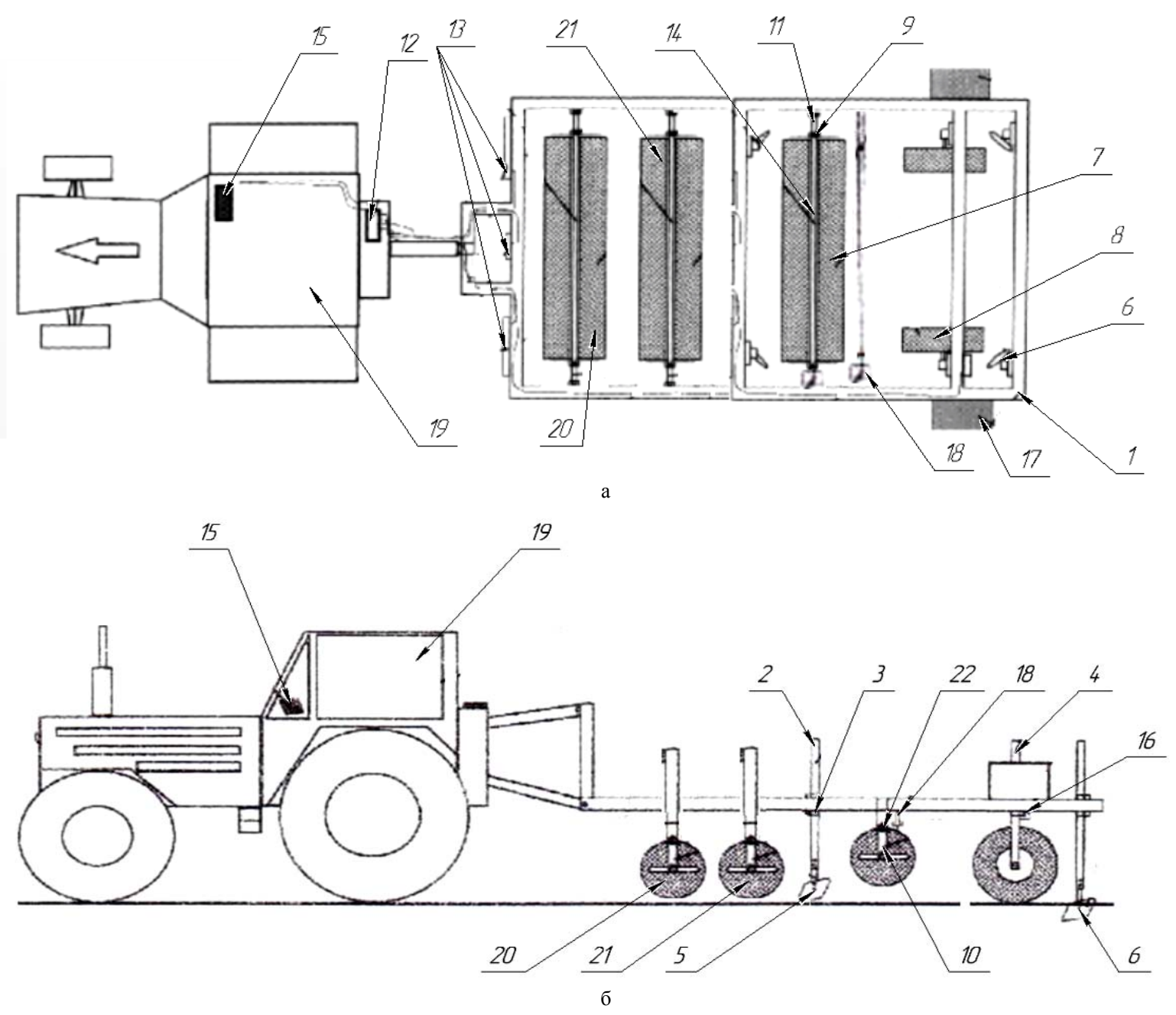

Рис. 1. Плівкоукладач для мізсрядного мульчування трунту: а-вигляд зверху; б- вигляд збоку 


\section{TEХНIЧНI НАУКИ}

При застосуванні міжрядного мульчування слід виконати оранку на глибину 20-25 см і боронування, для отримання рівного профілю поверхні грунту. Вологість грунту перед укриттям повинна бути не нижче 70 \% від найменшої стандартної вологоємності.

Запропонований плівкоукладач за технічним рішенням має зубовий коток (20), який 3’єднаний 3 прикочуючим котком (21). По ширині рами (1) встановлюються: вал (11) 3 рулоном плівки і кріплення (10) з обмежувачами переміщення рулону (9) та універсальний ніж, що обертається навколо вісі з фіксатором положення для відрізання плівки (18) з датчиком контролю витрати плівки (22), пристрій (12) для визначення напряму і швидкості руху укладача; датчик (16) визначення глибини i ширини смугизаглибини під прикочуючі колеса; датчик (13) розпізнавання рослин, датчик контролю витрати плівки (22) та комп'ютер (15) для обробки даних i внесення поправок в роботу укладача, створюється оптимальний тиск на прикочуючі колеса, які закріплені на основній стійці (4), регулюванням навантажувача (17).

Алгоритм роботи укладача. Краї плівки з рулону (7) захоплюються універсальними затискачами (14) і направляються під прикочуючі колеса (8). Напрям руху і швидкість укладача контролюється пристроєм (12) і дані передаються на комп'ютер для регулювання поправок. Під час руху укладача передній розгортач (5), який кріпиться на основній стійці (2) універсальними фіксаторами (3), робить рівні смуги-заглибини по ширині попереду прикочуючих коліс (8). Колеса прикочуючі під час руху укладача під визначеним оптимальним значенням навантажувача притискають краї плівки з рулона (7) до поверхні грунту, а задній пригортач (6) засипає плівку. Звільнюються затискачі (14) плівки і повертаються в вихідне положення, а плівка за рахунок природного натягу проходить по направляючих роликах і розгортається по поверхні грунту. В кінці смуги автоматично обрізується плівка, піднімається укладач плівки підйомником, розвертається трактор (19) і виходить на вихідне положення нової смуги і процес продовжується.

Методика планування дослідів та обробки результатів оптимізації параметрів плівкоукладача. Планування експерименту передбачало вибір числа та умов проведення дослідів необхідних та достатніх для вирішення поставленої мети 3 оптимізації параметрів плівкоукладача [1]. Для зменшення трудомісткості і тривалості експериментальних досліджень був використаний центральний композиційний ортогональний план, що передбачає проведення одного досліду, умови якого відповідають початковим досліджуваним факторам.

\section{1. Матриця планування та результати випробувань}

\begin{tabular}{|c|c|c|c|c|}
\hline $\begin{array}{c}\text { Номер } \\
\text { тесту }\end{array}$ & $\begin{array}{c}\text { Діаметр грунтопокрив- } \\
\text { ного диску, мм }\end{array}$ & $\begin{array}{c}\text { Падіння грунто- } \\
\text { вого покриття } \\
\text { диска, (мм) }\end{array}$ & $\begin{array}{c}\text { Швидкість } \\
\text { пересування }\end{array}$ & $\begin{array}{c}\text { Кваліфікований } \\
\text { рівень грунтового } \\
\text { покриву, У, \% }\end{array}$ \\
\hline 1 & 300 & 25 & 4,5 & 81,3 \\
\hline 2 & 350 & 25 & 4,5 & 91,9 \\
\hline 3 & 300 & 45 & 4,5 & 84,1 \\
\hline 4 & 350 & 45 & 4,5 & 80 \\
\hline 5 & 300 & 35 & 3 & 89,3 \\
\hline 6 & 350 & 35 & 3 & 82,4 \\
\hline 7 & 300 & 35 & 6 & 96,6 \\
\hline 8 & 350 & 35 & 6 & 87 \\
\hline 9 & 325 & 25 & 3 & 86,9 \\
\hline 10 & 325 & 45 & 3 & 89,5 \\
\hline 11 & 325 & 25 & 6 & 95,7 \\
\hline 12 & 325 & 45 & 6 & 98 \\
\hline 13 & 325 & 35 & 4,5 & 96,6 \\
\hline 14 & 325 & 35 & 4,5 & 97,5 \\
\hline 15 & 325 & 35 & 4,5 & 97,3 \\
\hline 16 & 325 & 35 & 4,5 & 4,5 \\
\hline 17 & 325 & 35 & & \\
\hline
\end{tabular}




\section{TEХНIЧНI НАУКИ}

Програмою досліджень передбачено зміну та контроль факторів: $X_{1}$ - швидкість руху агрегату, (3-6) км год ${ }^{-1} ; X_{2}$ - діаметр грунто-покривного диска (задній пригортач грунту згідно рис. 1), 300-350 мм; $X_{3}$ - падіння грунтового покриття диска (висота грунтового валика), 25-45 мм. При цьому визначались показники якості технологічного процесу, які є критеріями оптимізації роботи дослідного плівкоукладача запропонованої конструкції: $У$ - кваліфікований рівень грунтового покриву, \% (табл. 1).

Після проведення досліджень виконана статистична обробка результатів: встановлена залежність параметрів оптимізації від впливових факторів. Визначаємо вільний член, коефіцієнти регресії, перевірена значимість шляхом порівняння розрахункового критерію для кожного коефіцієнта з табличними даними $t_{\alpha ; n-l}$ за критерієм Стьюдента. Незначущі коефіцієнти виключені з рівняння регресії, а ті, що залишилися, перераховано заново.

Встановлена стандартна похибка коефіцієнта регресії та отримане рівняння:

$Y=97.02+1.82 x_{1}-1.31 x_{2}+1.61 x_{3}-5.71 x_{1}^{z}-6.98 x_{2}^{2}-3.44 x_{8}^{2}-3.67 x_{1} x_{2}+5.07 x_{1} x_{3}+1.65 x_{2} x_{8}$ (1)

Проведений аналіз отриманих математичних залежностей при коефіцієнті значущості $(\mathrm{P}<0,05)$ та $(\mathrm{P}<0,01)$.

Для аналізу взаємодії факторів та їх впливу на параметри оптимізації технологічного процесу укладання плівки дослідною установкою побудовані поверхні відгуку для значимих факторів. Аналіз поверхні дає можливість оцінити вплив діаметра та кута нахилу грунтопокривного диска з кваліфікованим рівнем грунтового покриву (рис. 1), вплив діаметру грунтопокривного диска та швидкості руху по висоті грунтового валика (рис. 2), вплив діаметра грунтопокривного диска та швидкістю руху по висоті (рис. 3). Для визначення динаміки випаровування вологи в залежності від типу покривного матеріалу були підготовлені зразки. В першу ємність був засипаний кульковий гідрогель «Агрікола», а зверху насипаний шар грунту, у другу - грунт і гель в тих же пропорціях, але поступово перемішаних один з одним. Після додавання однакової кількості води, необхідної для насичення грунту вологою і набухання гідрогелю, полив був припинений.

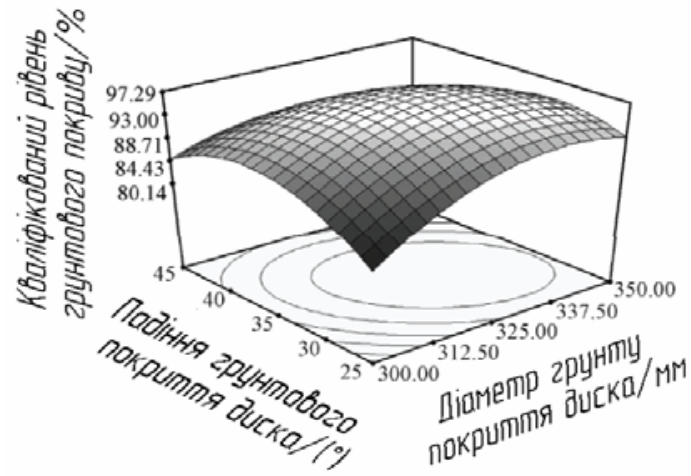

Рис. 2. Вилив діаметра та кута нахилу трунтового покриття диска з кваліфікованою швидкістю

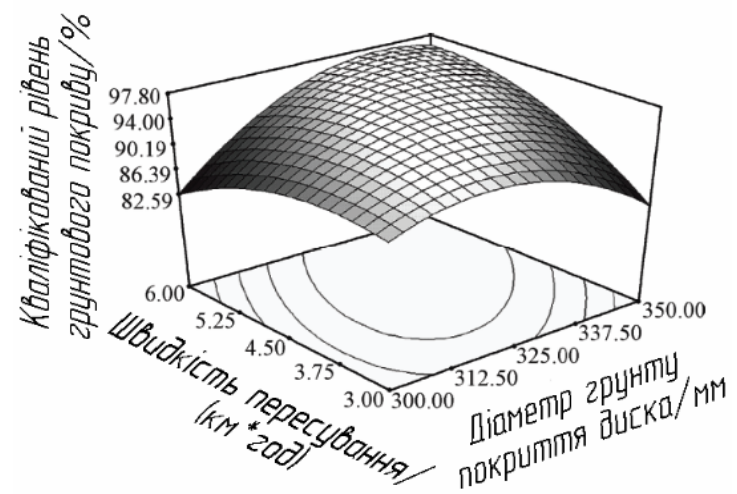

Рис. 3. Вплив діаметру трунтово-покривного диска та ивидкості руху по висоті 


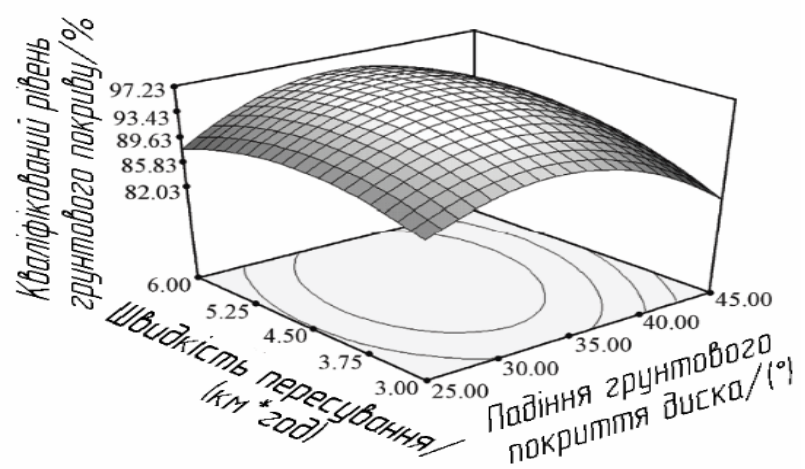

Рис. 4. Вплив занурення трунто-захисного диска зі ивидкістю руху по висоті

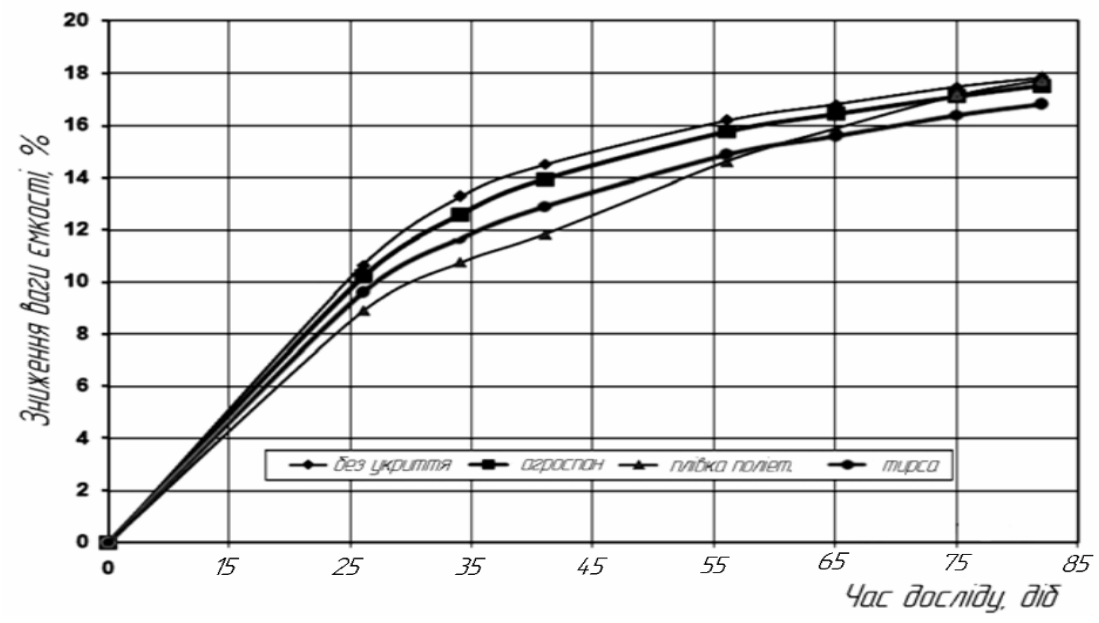

Рис. 5. Динаміка випаровування вологи в залежності від типу покривного матеріалу

Результати спостережень представлені на рисунку 5, з якого видно, що через 65 діб спостережень без поливу, в лівій ємності грунт практично висох (має більш світлий відтінок), а в правій ємності з розподіленим гідрогелем грунт зберіг вологу практично на всю глибину за винятком самого верхнього 3-сантиметрового шару.

Були поставлені з використанням запропонованого плівкоукладача досліди 3 вивчення впливу ширини плівки на термічний режим по глибині грунту. За результатами дослідів підтверджено характер кривих на рисунку 6 (Осипов I. М., Сисоліна I. П.). Польові досліди за визначенням раціональної висоти грунтових валиків, які утримують плівку на поверхні поля під час поривів вітру, показали, що без присипання країв грунтом плівка зноситься потоком повітря 3 поверхні поля вже за швидкості вітру 1,3 м/с.

Також дослідженням було встановлено, що за допомогою зубового та прикочуючого котків забезпечується якісне рихлення грунту та виключається нерівномірність поверхні поля.

Досліди з визначення раціональної висоти грунтових валиків для утримання плівки здійснювалися 3 плівкою П-37 завширшки 0,5 м. Довжина смуг плівки - 50 м. Швидкість повітря змінювалася від 0 до $18 \mathrm{~m} / \mathrm{c} 3$ інтервалом $3 \mathrm{~m} / \mathrm{c}$ і замірялася перед грунтовим валиком анемометром АП-1.

Польові досліди з вивчення впливу ширини плівки на гідротермічний режим грунту здійснювалися 3 плівкою завширшки від 0,1 м до 0,7 м 3 кроком 0,1 м, довжина смуг плівки становила 50 м. Температура грунту замірялася ртутним термометром на глибині $6 \mathrm{~cm} 3$ через кожну годину впродовж 5 годин (з 1000 до 1500).

Результати проведених досліджень щодо впливу ширини плівки на термічний режим грунту показали, що температура грунту на глибині 6 см зі збільшенням ширини плівки від 20 до 40 см істотно збільшується, а $з$ плівкою завширшки 60 і 80 см має майже однакові показники (рис. 6).

Дослідженням було доведено, що доцільно використати плівку завширшки близько $45 \mathrm{~cm}$. Використання плівки ширшої, ніж 45 см ускладнюватиме конструкцію плівкоукладача, підвищуватиме трудомісткість його обслуговування, не створюючи істотних переваг у поліпшенні термічного режиму грунту. 


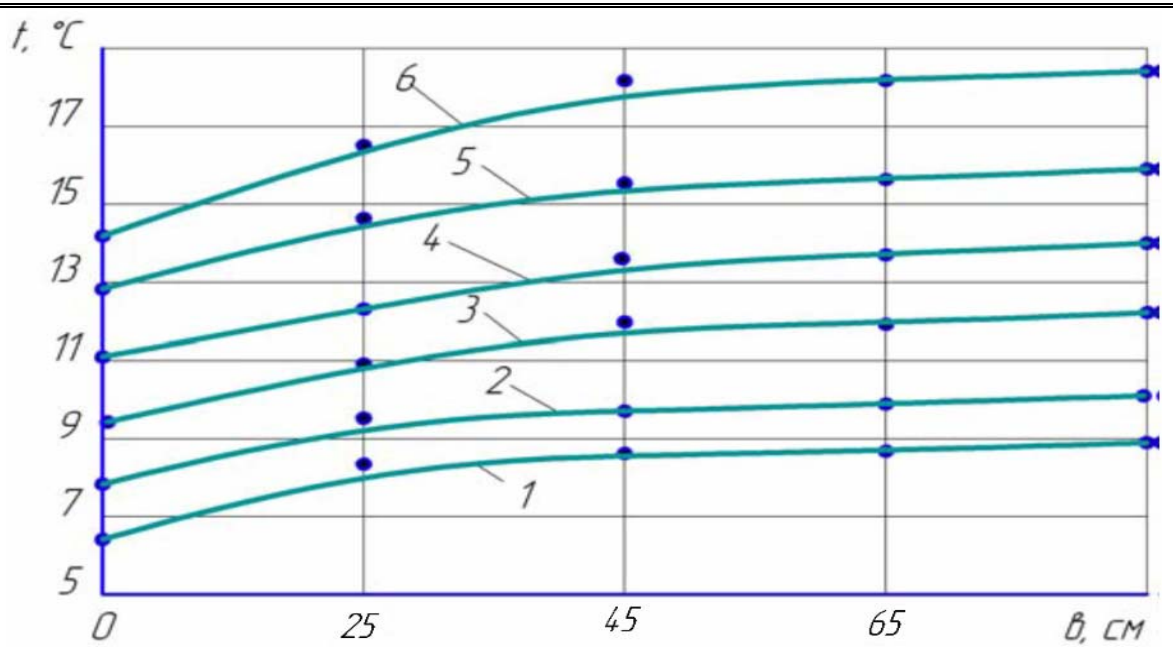

Рис. 6. Вплив иирини плівки на термічний режим трунту з 950 до 1550 у похмуру погоду: 1 - 950; 2 - 1150; 3 - 1250; 4-1350; 5-1450; 6-1550

Також результати дослідження підтвердили, що під плівкою в похмуру погоду температура була на $2-3{ }^{\circ} \mathrm{C}$ вище, а в сонячну - на $10-12{ }^{\circ} \mathrm{C}$.

Висновок. Результати проведених досліджень підтверджують доцільність застосування запропонованого плівкоукладача.

Аналіз результатів досліджень показав високу вологозберігаючу ефективність поліетиленової плівки, тобто вкриті нею ємності 3 грунтом утримували вологу довше за інших. Польові досліди 3 визначення раціональної висоти грунтових гребнів, які утримують плівку на поверхні поля під час поривів вітру, показали, що без присипання країв грунтом плівка зноситься потоком повітря з поверхні поля вже за швидкості вітру 1,3 м/с. Досліди з визначення раціональної висоти грунтових гребнів для утримання плівки здійснювалися 3 плівкою П-37 завширшки 0,5 м та довжиною смуг плівки 50 м. Швидкість повітря змінювалася від 0 до $18 \mathrm{~m} / \mathrm{c} 3$ інтервалом $3 \mathrm{~m} / \mathrm{c}$ і замірялася перед грунтовим гребнем анемометром АП-1. Засипання країв плівки грунтом протистоїть поривам вітру і досить засипати краї плівки грунтовими гребнями заввишки 65-85 мм, щоб шквальний вітер $(18 \mathrm{~m} / \mathrm{c})$ iї не здував.

Температура грунту замірялася ртутним термометром на глибині 6-7 cм через кожну годину впродовж 5 годин (з 10.00 до 15.00).

Результати проведених досліджень щодо впливу ширини плівки на термічний режим грунту показали, що температура грунту на глибині 6 см зі збільшенням ширини плівки від 25 до

\section{БІБЛІОГРАФІЯ}

1. Барабащюк В. И., Креденщер Б. П., Мирошниченко В. И. Планирование эксперимента в технике. - К. : Техника, 1984. - 200 с.
45 см істотно збільшується, а 3 плівкою завширшки 65,85 см має майже однакові показники.

Отже, ця конструкція дозволяе здійснювати ефективне вкладання плівки у грунт, покращуючи умови сходження насіння, i придатна для роботи в усіх грунтово-кліматичних зонах України.

За результатами дослідів побудовані рівняння регресії і проведена оцінка їх адекватності та встановлене оптимальне співвідношення факторів, яке забезпечує отримання показника мінімальної $X_{1}$ - швидкість пересування, км · год ${ }^{-1} ; X_{2}$ - діаметр диска покритого грунтом, мм; $X_{3}$ - падіння грунтового покриття диска, мм, при якому буде забезпечено якісне розгортання плівки. Для відображення впливу даних факторів встановлено залежності параметрів оптимізації від впливових факторів: діаметра та кута нахилу грунтового покриття диска 3 кваліфікованою швидкістю; діаметру та глибини занурення грунтовопокривного диска та швидкості руху по висоті. Визначено вплив покриття поверхні грунту на динаміку випаровування вологи в залежності від часу спостережень. Встановлено вплив ширини плівки на термічний режим грунту.

За результатами виробничих досліджень визначено техніко-економічну ефективність впровадження плівкоукладача на етапі випробування згідно ДСТУ 4397:2005. Отриманий річний економічний ефект від експлуатації машини з урахуванням кількості та якості продукції становить 24024 грн. Використання плівкоукладача має сезонний характер і окупиться за один рік.

2. Кондратеи Л. М. Применение светоразрушающей пленки // Кукуруза и сорго. - №3. 1985. - C. 16-17. 


\section{TEХНIЧНI НАУКИ}

3. Осипов I. М., Сисоліна І. П. Розробка конструкції плівкоукладача до кукурудзяної сівалки : матеріали $\mathrm{X}$ Міжнародної науково-практичної конференції. Проблеми конструювання, виробництва та експлуатації сільськогосподарської техніки. - Кіровоград : КНТУ, 2015. - С. 71-72.

4. Патент №111083 (МПК A01G 13/02 2006.01) Бюл. № 20 25.10.2016 Укладач плівки в тепличному господарстві кооперативу Литвин О. Ю., Дорогань-Писаренко Л. О., Аранчій В. І., Чіп Л. О., Галич О. А., Горб О. О., Махмудов Х. 3., Слинько В. Г., Березницький В. І., Федій Б. С., Прасолов С. Я.

5. Шмат С. И. Тенденции использования пленки для посева сельскохозяйственных культур. Информация / УкрНИИНТИ. - 1988. - 17 с.

6. Xiaoze Yu, Mingjin Xin, YuqiuSong Wentao Ren. Design and Test of Key Components of Paper Mulching Mechanism for Paddy Field. Shenyang
Agricultural University. - Shen Yang 110866, China Inner Mongolia University For Nationlities, TongLiao 028000, China.

7. Das Folieamulch-Saatverfahren bei Mais-Gang der Entwicklung // Lohnuntehnehmen in LandForstwirtsch. - №1. - 1983 (ar DE 8.15).

8. Journal of Advances in Science and Technology - Vol. 13, Issue 1 (Special Issue) March 2017, ISSN 2230-9659.

9. Padawal N. T., Mali R. D., Nandgavakar S. D., Suryavanshi Vishwas Ramdas, Umesh P. Sutar, Duradundi Sawant Badkar. Desing and Development of New Mulching Machine for Agriculture Journal of Advances in Science and Technology Vol. 13, Issue 1 (Special Issue) March 2017, ISSN 2230-9659.

10. Xromer K. H., Estler M. Maisanbau mit Folie // Landtechnik. - №6. - 1981. - P. 291.

wheels. Wheels moving during loading of the compiler under the certain optimum values of the loader press the edges of the plumbing from the roll to the surface of the soil, and the rear trap clogs the film. Releases the clips of the film and return to the original position, and the plumbing at the expense of the natural tension passes through the guide rollers and unfolds along the surface of the soil. At the end of the strip, the plumbing is automatically trimmed, the plumbing machinery is raised by the lift, the tractor turns and goes to the starting position of the new strip and the process continues. Matrix planning was used to reduce the complexity and duration of the research. The dependencies of optimization parameters on influential factors are established: the diameter and angle of the soil surface of the disk with the qualified speed; diameter and depth of submersion of the soilcovering wheel and speed of movement in height. The influence of the surface of the soil on the dynamics of moisture evaporation, depending on the time of observation, is determined. The influence of the width of the plumbing on the thermal regime of the soil is established. The results of the research were tested in the PP agricultural firm «Anastasia» and LLC AF «named after Dovzhenko» VF AF "Ordanivka». The use of the plumbing is seasonal and will pay off in one year.

Key words: plumbing machinery, agrotechnical measures, milling, spacing, soil processing, disc. 